\title{
A Comparative Study on the Optoelectronic Performance of Undoped, Mg-doped and F/Mg Co-doped ZnO Nanocrystalline Thin Films for Solar Cell Applications
}

\author{
Warda Darenfad ${ }^{1, *}$, Noubeil Guermat ${ }^{1,2}$, Kamel Mirouh ${ }^{1}$ \\ 1 Thin Films and Interfaces Laboratory (LCMI), University of Brothers Mentouri of Constantine 1, \\ 25000 Constantine, Algeria \\ 2 Department of Electronics, Faculty of Technology, University Mohamed Boudiaf of M'sila, 28000 M'sila, Algeria
}

(Received 03 October 2021; revised manuscript received 02 December 2021; published online 20 December 2021)

\begin{abstract}
This work reports on the development and characterization of Zinc Oxide $(\mathrm{ZnO})$ nanocrystalline thin films deposited on glass substrates by spray pyrolysis method. The effect of $1 \% \mathrm{Mg}$-doping and $6 \% \mathrm{~F} /$ $x \% \mathrm{Mg}$ co-doping ( $x=1,2$ and 3 ) on the structural, morphological, optical and electrical properties of the films obtained is studied. The structural characterization shows that all the deposited layers are polycrystalline with a hexagonal wurtzite-type structure due to the existence of a more intense peak relative to the (002) peak, located around an angle of $34.13^{\circ}$ with no other phase detected. The measured contact angles are more than $90^{\circ}$ for pure, doped and $6 \% \mathrm{~F} / 1 \% \mathrm{Mg}$ co-doped films prepared, which confirms the hydrophobic character, while other co-doped films (6\% F:2 \% Mg and $6 \% \mathrm{~F}: 3 \% \mathrm{Mg}$ ) show the hydrophilic character at values of the contact angle $<90^{\circ}$. A higher transmittance value of $86.47 \%$, a wide band gap of $3.53 \mathrm{eV}$ and lower disorder (330.03 meV) are observed for the $6 \% \mathrm{~F}: 1 \% \mathrm{Mg}$ co-doped film. Co-doping with $1 \% \mathrm{Mg}$ considerably improves the electrical conductivity $\left(\sigma=0.030(\Omega . \mathrm{cm})^{-1}\right)$. The results suggest that the co-doped $\mathrm{ZnO}$ film (6 \% F, $1 \% \mathrm{Mg})$ can be used as a window film in thin film solar cells.
\end{abstract}

Keywords: Thin films, F/Mg co-doped ZnO, Spray pyrolysis, Contact angle, Hydrophobic, Hydrophilic.

\section{INTRODUCTION}

Currently, II-VI semiconductor compounds have been widely studied by researchers due to their remarkable performance in optics and electronics. Zinc oxide $(\mathrm{ZnO})$ is one of the most widely used II-VI semiconductors in optoelectronics because of its excellent photoelectric properties due to the high exciton binding energy $(60 \mathrm{meV})$ at $300 \mathrm{~K}$ and a wide band gap $(\approx 3.2$ $3.37 \mathrm{eV}$ ) [1]. These properties make $\mathrm{ZnO}$ an effective material for various optoelectronic devices, such as thin film solar cells, photonic devices, laser systems, light emitting diodes, flexible screens, and surface acoustic wave devices. In general, two methods of physical and chemical synthesis are used to make $\mathrm{ZnO}$ thin films. Among them, we are interested in the work in the spray pyrolysis technique, which is a simple chemical method, profitable and which allows to adapt a doping element in the host matrix of $\mathrm{ZnO}$ films [2,3]. To modify these physical properties for a wide range of possible applications, $\mathrm{ZnO}$ films are doped or co-doped with various elements such as $\mathrm{Mg}, \mathrm{Co}, \mathrm{Ni}, \mathrm{Sb}, \mathrm{F}, \mathrm{Mn}, \mathrm{Cr}$ and $\mathrm{N}$. The selection of the doping element aims to improve the optical and electrical properties of $\mathrm{ZnO}$ nanomaterials for optoelectronic devices [2]. These properties can be further improved by varying the stoichiometric ratio of the doping element in the host material [1]. Among the different doping elements, particular attention is paid to the incorporation of fluorine (F), which, acting as an anionic impurity, leads to resistivity values that are lower than those obtained for the most appropriate cationic impurities such as $\mathrm{ZnO}: \mathrm{In}$ with a resistivity of the order of $210^{-3} \Omega \cdot \mathrm{cm}$ [4]. In addition, fluorine is an attractive dopant due to its high electronegativity and low ionization energy [5]. Accord- ing to the literature [6], the lowest value of the resistivity obtained for $\mathrm{ZnO}: \mathrm{F}$ deposited by spray is of the order of $210^{-2} \Omega \cdot \mathrm{cm}$. Another factor to be taken into account, which can mainly affect the optical properties, is the wide optical gap. In this regard, we are interested in this study of the transition element magnesium (Mg) for two reasons: (i) the solubility of solid $\mathrm{MgO}$ in $\mathrm{ZnO}$ is high, (ii) due to the wide band gap of $\mathrm{MgO}$ $(\approx 7.8 \mathrm{eV}$ ), doping with $\mathrm{Mg}$ can widen the optical band gap of $\mathrm{ZnO}$ and the UV luminescence intensity of the systems, making them suitable for optoelectronic applications. Therefore, $\mathrm{Mg}$ is chosen as the initial doping element of $\mathrm{ZnO}$ and is limited to $3 \%$ to avoid the formation of a secondary phase $(\mathrm{MgO})$ [7]. To our knowledge, there are few papers on the combined effect of $\mathrm{Mg}$ and $\mathrm{F}$ as dopants to improve the physicochemical properties of $\mathrm{ZnO}$ for application in thin film solar cells. For all these reasons, we are working on this contribution to enrich this research area. Moreover, in this work, thin films of pure $\mathrm{ZnO}, \mathrm{Mg}$-doped and $\mathrm{F} / \mathrm{Mg}$ codoped were developed by the method of spray pyrolysis, and their structural, optical and electrical properties were studied in detail.

\section{EXPERIMENTAL DETAILS}

$\mathrm{ZnO}$ thin layers were prepared using $1.097 \mathrm{~g}$ of dehydrated zinc acetate $\left(\mathrm{Zn}\left(\mathrm{CH}_{3} \mathrm{COO}\right)_{2} \cdot 2 \mathrm{H}_{2} \mathrm{O}\right)$ as a precursor, dissolved in methanol at a molar concentration of the solution equal to $0.1 \mathrm{M}$. Addition of any drop of hydrochloric acid is necessary to ensure maximum dissolution of $\mathrm{Zn}\left(\mathrm{CH}_{3} \mathrm{COO}\right)_{2} \cdot 2 \mathrm{H}_{2} \mathrm{O}$. After 10 min under magnetic stirring at room temperature, an adequate quantity of magnesium $\left(\mathrm{Mg}\left(\mathrm{CH}_{3} \mathrm{COO}\right)_{2} \cdot 4 \mathrm{H}_{2} \mathrm{O}\right)$ and fluorine $\left(\mathrm{NH}_{4} \mathrm{~F}\right)$ with different doping rates was consid-

\footnotetext{
*daranfed.warda@umc.edu.dz
} 
ered. Five samples were obtained: pure $\mathrm{ZnO}, 1 \% \mathrm{Mg}$ doped $\mathrm{ZnO}, 6$ \% F/1 \% Mg co-doped $\mathrm{ZnO}, 6 \% \mathrm{~F} / 2 \% \mathrm{Mg}$ co-doped $\mathrm{ZnO}$, and $6 \% \mathrm{~F} / 3 \% \mathrm{Mg}$ co-doped $\mathrm{ZnO}$. The final solution was deposited by spray pyrolysis on glass substrates, the deposition time of each sample was $10 \mathrm{~min}$. The substrate temperature was fixed at $400{ }^{\circ} \mathrm{C}$, the carrier gas (compressed air) and the solution were fed into the spray nozzle at a pre-adjusted constant atomization pressure. The nozzle to substrate distance was $17 \mathrm{~cm}$. The structural properties were determined by XRD using a Philips X' Pert system with $\mathrm{CuKa}$ radiation $\left(\lambda_{\mathrm{CuK}_{\alpha}}=1.5418 \AA\right)$. The values of the contact angle of each deposit were obtained after $5 \mathrm{~s}$ with a $5 \mu \mathrm{l}$ drop of distilled water. Measurements of optical transmission in the UV-Visible range $(300-800 \mathrm{~nm})$ were performed using a Shimadzu UV-3101 PC spectrophotometer. The electrical properties, mainly the resistivity of thin films, were characterized at room temperature by the four-probe method using Keithley 2401 .

\section{RESULTS AND DISCUSSION}

Fig. 1 shows the X-ray diffraction spectra of our films. According to Fig. 1, we notice the presence of layers based on pure $\mathrm{ZnO}$, doped and co-doped. The same diffraction peaks located at $31.61,34.13,35.97$, $47.30,56.12,62.41$ and $67.68^{\circ}$ are assigned to the planes (100), (002), (101), (102), (112), (103) and (200), respectively. According to ASTM files (JCPDS 36-1451 [2]), the resulting layers are polycrystalline with a hexagonal wurtzite-type structure due to the existence of a more intense peak related to the (002) orientation located around $34.18^{\circ}$ for all layers deposited. In other words, no additional peaks corresponding to $\mathrm{Mg}$ and $\mathrm{F}$ and $\mathrm{MgO}$ and $\mathrm{ZnF}_{2}$ compounds are detected in the XRD spectra of $\mathrm{ZnO}$ films doped with $1 \% \mathrm{Mg}$ or co-doped with $0 \% \mathrm{~F}: \% \mathrm{Mg}$. This indicates that the hexagonal wurtzite structure of our films is not altered in the presence of $\mathrm{Mg}$ and $\mathrm{F}$ as impurity atoms. However, the (002) peak became more intense and narrower for a film co-doped with $6 \% \mathrm{~F}: 1 \% \mathrm{Mg}$. This behavior is probably due to the improved crystallinity of this film. In addition, still following the same figure for the films co-doped with 2 and $3 \% \mathrm{Mg}$, the intensity of the (002)

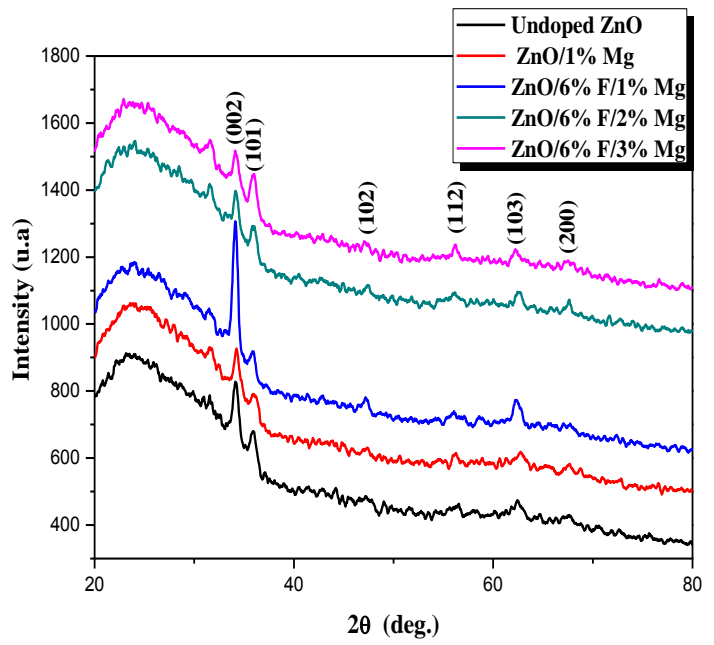

Fig. 1 - X-ray diffraction spectra of the obtained films with different doping and co-doping concentrations

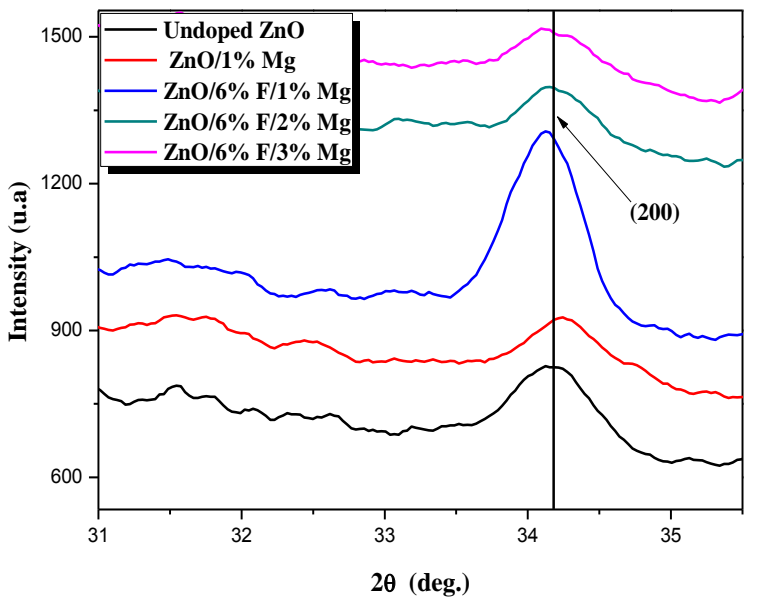

Fig. 2 - X-ray diffraction (002) peaks and their intensities for processed films

peak decreases again. The reason is that the crystallinity of our samples decreases when more $\mathrm{Mg}$ atoms are incorporated into the crystal lattice.

In order to study the incorporation of $\mathrm{Mg}$ and $\mathrm{F}$ into the $\mathrm{ZnO}$ matrix, the maximum position of the (002) peak is monitored. Fig. 2 shows a zoom of the (002) peak of our films. As seen from Fig. 2, the peak of the $\mathrm{Mg}$-doped $\mathrm{ZnO}$ sample clearly shows a shift from the center of the (002) peak to a higher angle compared to that of pure $\mathrm{ZnO}$. This result is in good agreement with those published by several authors [8, 9]. According to Verma et al. [8], this slight shift of the (002) peak to a higher angle with the addition of $1 \% \mathrm{Mg}$ doping is due to the possible substitution of $\mathrm{Mg}^{2+}$ in the $\mathrm{ZnO}$ matrix, which results in a slight deformation of the crystal lattice. We also note the shift of the peak towards lower angles observed for co-doped films ( $\mathrm{ZnO}: 6 \% \mathrm{~F}: 1 \% \mathrm{Mg}$, $\mathrm{ZnO}: 6 \% \mathrm{~F}: 2 \% \mathrm{Mg}$ and $\mathrm{ZnO}: 6 \% \mathrm{~F}: 3 \% \mathrm{Mg}$ with offsets of $34.12,34.14$, and $34.12^{\circ}$, respectively) as compared to pure $\mathrm{ZnO}$ film $\left(34.18^{\circ}\right)$. Such a reduction in the lattice parameter can be attributed to the smaller ionic radius of $\mathrm{Mg}^{2+}(0.066 \mathrm{~nm})$ [1] compared to that of $\mathrm{Zn}^{2+}$ $(0.074 \mathrm{~nm})[1,10]$; the radius of $\mathrm{F}^{-}$ions $(0.131 \mathrm{~nm})$ is smaller than that of $\mathrm{O}^{-2}$ ions $(0.138 \mathrm{~nm})$ [11]. In addition, this indicates that the lattice parameters of $\mathrm{Mg}$ and F-doped films are smaller than those of $\mathrm{ZnO}$ films [10]. This is similar to the results reported in the literature, such as $\mathrm{Al}$-doped $\mathrm{ZnO}$ [10], In-doped $\mathrm{ZnO}, \mathrm{Mg}$ doped $\mathrm{ZnO}$ thin films [12]. Therefore, the variation of the lattice parameter signifies the incorporation of $\mathrm{Mg}^{2+}$ and $\mathrm{F}^{-}$due to doping and co-doping.

The crystallite sizes $(D)$ of the $(002)$ peak were calculated from the Debye-Scherrer formula $[2,3,13]$ :

$$
D=\frac{0.9 \lambda}{\beta \cos \theta}
$$

where $\lambda$ is the wavelength of $\mathrm{X}$-ray radiation, $\beta$ represents the full width at half maximum (FWHM) and $\theta$ is the angle of diffraction.

The strain values $(\varepsilon)$ of the $\mathrm{ZnO}$ film along the (002) plane are calculated using the following formula:

$$
\varepsilon=\frac{\beta \cos \theta}{4} .
$$


Table 1 - Variation of crystallite size and strain of our films

\begin{tabular}{|l|c|c|}
\hline \multicolumn{1}{|c|}{ Sample type } & $D, \mathrm{~nm}$ & Strain $(\varepsilon) \times 10^{-3}$ \\
\hline Undoped ZnO & 16.986 & 2.040 \\
\hline $\mathrm{ZnO}: 1 \% \mathrm{Mg}$ & 16.954 & 2.043 \\
\hline $\mathrm{ZnO}: 6 \% \mathrm{~F}: 1 \% \mathrm{Mg}$ & 19.149 & 1.810 \\
\hline $\mathrm{ZnO} 6 \% \mathrm{~F}: 2 \% \mathrm{Mg}$ & 17.557 & 1.973 \\
\hline $\mathrm{ZnO}: 6 \% \mathrm{~F}: 3 \% \mathrm{Mg}$ & 16.366 & 2.121 \\
\hline
\end{tabular}

Table 1 summarizes the crystallite sizes $(D)$ and the strain values $(\varepsilon)$ at different doping and co-doping concentrations. It is seen from Table 1 that the variation of strain is inversely proportional to the crystallite size. According to the literature $[2,3,5]$, a similar phenomenon has already been observed by other researchers. Consistent with the variation in the intensity of the diffraction peak with doping and co-doping, the strain decreased at a $\mathrm{Mg}$ concentration of 1 and $2 \%$ upon codoping and increased upon doping $(1 \% \mathrm{Mg})$ and the highest co-doping (6 \% F:3 \% Mg). For $6 \% \mathrm{~F}: 1 \% \mathrm{Mg}$ codoping, the minimum strain of $1.810 \times 10^{-3}$ and the largest crystallite size of $19.149 \mathrm{~nm}$ are obtained. According to $[2,5]$, the increase in the crystallite size is interpreted by the better crystallinity of the film produced. These results indicate that $\mathrm{ZnO}: 6 \% \mathrm{~F}: 1 \% \mathrm{Mg}$ film has the best crystal quality.
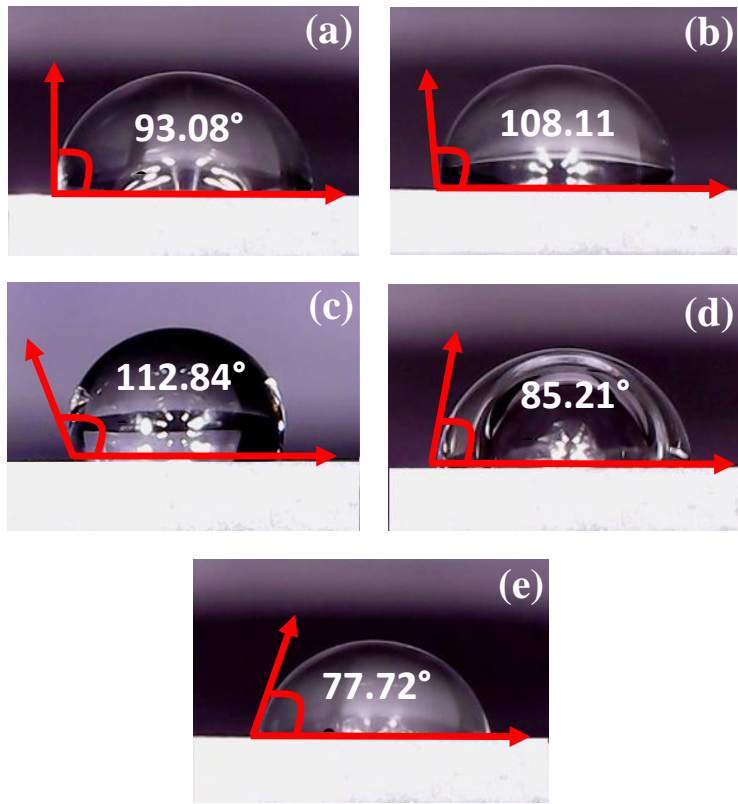

Fig. 3 - Water contact angles of $\mathrm{ZnO}$ thin films deposited with different dopant

Table 2 illustrates the variation of contact angle for different films produced. From Table 2 we see an increase in the contact angle from $93.08^{\circ}$ for an undoped film to $112.45^{\circ}$ for $6 \% \mathrm{~F} / 1 \% \mathrm{Mg}$ co-doped film, on the one hand. On the other hand, we also notice a decrease in the contact angle for $6 \% \mathrm{~F} / 2 \% \mathrm{Mg}$ and $6 \% \mathrm{~F} / 3 \% \mathrm{Mg}$ co-doped films from $85.21^{\circ}$ to $77.72^{\circ}$, respectively. The same behavior was observed by Cho et al. [14]. Following the work of Cho et al. [14], this variation is due to the surface morphology of the films produced by contact with a water drop. In addition, the contact angle values found for undoped, Mg-doped and $6 \% \mathrm{~F}: 1 \% \mathrm{Mg}$ co-doped films are $>90^{\circ}$, which shows the hydrophobic character of the deposited films. On the other hand, for other co-doped films, the hydrophilic character manifests itself at contact angle values $<90^{\circ}$; this character demonstrates that these films are a promising material for photocatalytic applications and as a sensitive layer in gas sensors.

Table 2 - Variation of contact angle of undoped, Mg-doped and $\mathrm{F} / \mathrm{Mg}$ co-doped $\mathrm{ZnO}$ films

\begin{tabular}{|l|c|}
\hline \multicolumn{1}{|c|}{ Sample type } & Water contact angle, $^{\circ}$ \\
\hline Undoped $\mathrm{ZnO}$ & 93.08 \\
\hline $\mathrm{ZnO}: 1 \% \mathrm{Mg}$ & 108.11 \\
\hline $\mathrm{ZnO}: 6 \% \mathrm{~F}: 1 \% \mathrm{Mg}$ & 112.45 \\
\hline $\mathrm{ZnO}: 6 \% \mathrm{~F}: 2 \% \mathrm{Mg}$ & 85.21 \\
\hline $\mathrm{ZnO}: 6 \% \mathrm{~F}: 3 \% \mathrm{Mg}$ & 77.72 \\
\hline
\end{tabular}

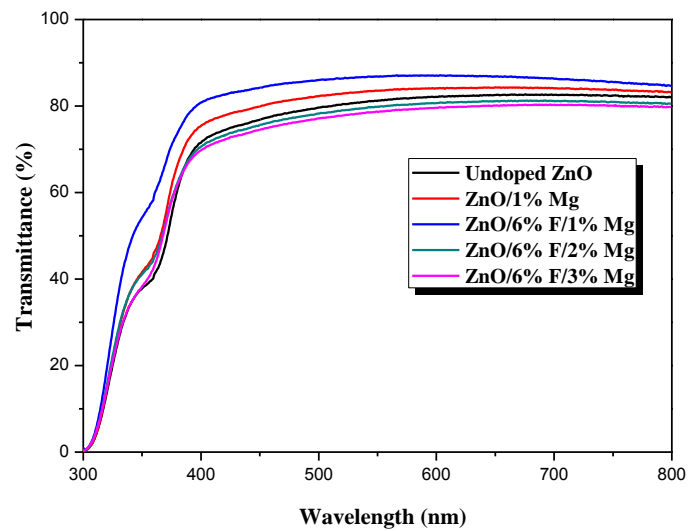

Fig. 4-Transmission spectra of $\mathrm{ZnO}$ thin films deposited with different doping elements

A UV-visible spectrophotometer was used to study and analyze films of pure, doped with $\mathrm{Mg}$ and co-doped with F/Mg (Fig. 4). For all films, the average transmittance for the visible wavelength region $\lambda=300-800 \mathrm{~nm}$ was greater than $80 \%$. When the molar doping amount of $\mathrm{Mg}^{2+}$ is $1 \%$, the transmittance is remarkably improved in the visible and near infrared regions with a high value of $86.47 \%$ for $6 \% \mathrm{~F}: 1 \% \mathrm{Mg}$ co-doped film. For comparison, the transmittance obtained in this work for $\mathrm{ZnO}$ film co-doped with $6 \% \mathrm{~F}: 1 \% \mathrm{Mg}$ $(86.47 \%)$ is higher than that found by Snega et al. [15] for $\mathrm{ZnO}$ film co-doped with $20 \% \mathrm{~F}: 4 \% \mathrm{Mg}(T=85 \%)$ deposited by spray pyrolysis. This improvement can be attributed to various reasons such as particle size, oxygen deficiency, surface roughness and thickness. According to Guermat et al. [2], the high transparency of $6 \% \mathrm{~F}: 1 \% \mathrm{Mg}$ co-doped film is probably due to the low dispersion effect resulting from structural homogeneity and improved crystallinity of the deposited thin film. The same behavior was observed by Rath et al. [16], studying $\mathrm{ZnO}$ films for different levels of $\mathrm{Mg}$. With increasing $\mathrm{Mg}$ concentration (2 and $3 \%$ ), transmission decreases. This behavior is in good agreement with [7]. According to Liu et al. [7], doping with $\mathrm{Mg}^{2+}$ cations in the $\mathrm{ZnO}$ lattice should modify the chemical and physical properties of $\mathrm{ZnO}$, in particular, the optical properties. Therefore, it can be concluded that the transmittance is improved by the good incorporation of fluorine and magnesium into the structure of $\mathrm{ZnO}$ for the concentration of $\mathrm{Mg}$ equal to $1 \%$. 
To better see the effect of doping and co-doping on the behavior of $\mathrm{ZnO}$ films, we increased the transmittance slices at the level of the fundamental absorption zone in the UV region for lengths $\leq 400 \mathrm{~nm}$, as illustrated in Fig. 5. For a wavelength of $400 \mathrm{~nm}$, it can be seen that the transmittance patterns clearly evoke the chut due to the interband absorption (the fundamental absorption). The shift towards shorter wavelengths for films of pure, Mg-doped and co-doped with $\mathrm{F} / \mathrm{Mg}$ (ZnO:6 \% F:1 \% Mg), which reflects the Burstein-Moss (BM) effect [13] and manifests in increased transmission in the UV region, is an advantageous characteristic for thin film solar cell applications because it allows more high-energy photons to hit the solar cell. According to Fig. 5, the opposite effect is also observed, the shift of the absorption tail towards longer wavelengths for another co-doping is reflected in the Roth effect [13]. Therefore, it can be concluded that $6 \% \mathrm{~F}: 1 \% \mathrm{Mg}$ doping and co-doping improve the transmittance.

The direct band gap energy $\left(E_{g}\right)$ for films of undoped, $\mathrm{Mg}$-doped and $\mathrm{F} / \mathrm{Mg}$ co-doped $\mathrm{ZnO}$ is estimated from the plots of $(a h v)^{2}$ versus the photon energy $h v$, as shown in Fig. 6, using the Tauc's equation [2, 3, 17, 18]. The linear part of these graphs is extrapolated to the energy axis, and the energy value at $(\alpha h v)^{2}=0$ gives the value of $E_{g}$. The values obtained for our films are listed in Table 3.

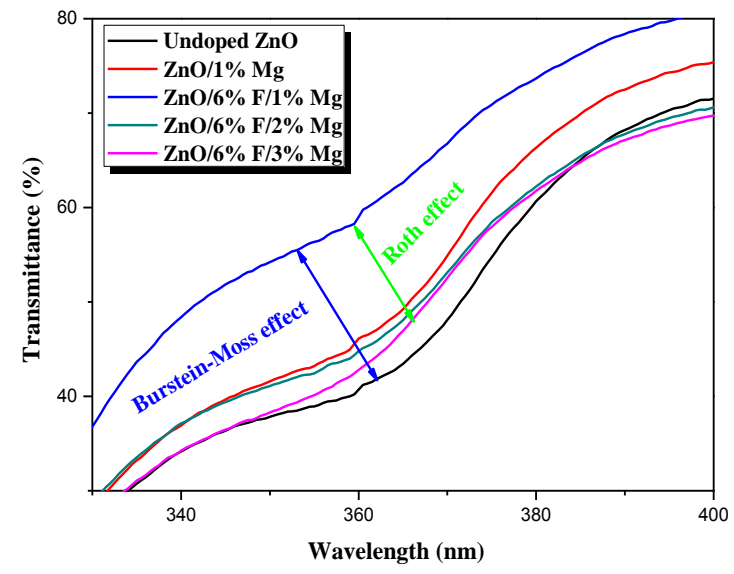

Fig. 5 - Zoom of the transmittance spectra for $\lambda=400 \mathrm{~nm}$ of our films

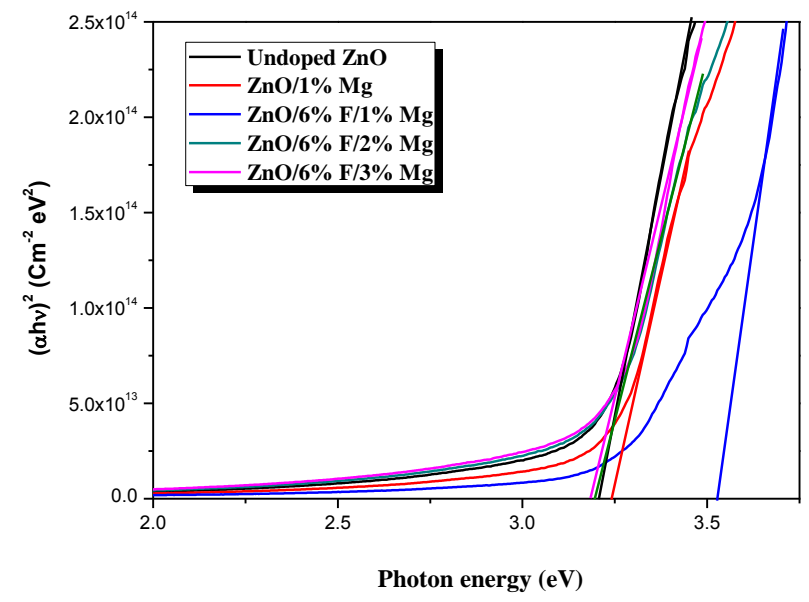

Fig. 6 - Tauc's plots for determining the optical band gap energy of $\mathrm{ZnO}$ thin films deposited with different dopant
Table 3-Values of optical parameters of $\mathrm{ZnO}$ thin films deposited with different dopant

\begin{tabular}{|l|c|c|}
\hline \multicolumn{1}{|c|}{ Sample type } & $E_{g}, \mathrm{eV}$ & $E_{U}, \mathrm{eV}$ \\
\hline Undoped $\mathrm{ZnO}$ & 3.21 & 335.57 \\
\hline $\mathrm{ZnO}: 1 \% \mathrm{Mg}$ & 3.24 & 332.22 \\
\hline $\mathrm{ZnO} 6 \% \mathrm{~F}: 1 \% \mathrm{Mg}$ & 3.53 & 330.03 \\
\hline $\mathrm{ZnO}: 6 \% \mathrm{~F}: 2 \% \mathrm{Mg}$ & 3.20 & 337.83 \\
\hline $\mathrm{ZnO}: 6 \% \mathrm{~F}: 3 \% \mathrm{Mg}$ & 3.18 & 348.43 \\
\hline
\end{tabular}

It can be seen from Table 3 that the $E_{g}$ values for our processed films are between 3.18 and $3.53 \mathrm{eV}$. This variation of the optical gap is in good agreement with the values found in the literature [19]. According to Table 3, the optical gap of $\mathrm{ZnO}$ films doped and co-doped with $1 \% \mathrm{Mg}$ first increases with a difference of $0.32 \mathrm{eV}$ for $6 \% \mathrm{~F}: 1 \% \mathrm{Mg}$ co-doped film $\left(E_{\operatorname{gmax}}=3.53 \mathrm{eV}\right)$, then decreases, while the amount of the doping element $\mathrm{Mg}$ gradually increases (2 and $3 \%$ ). This result is in agreement with those published by several authors [5, $14,20]$. An increase and decrease in $E_{g}$ under the influence of doping and the size effect has been reported in the literature [20]. The increase in the optical gap for $\mathrm{ZnO}$ film doped with $1 \% \mathrm{Mg}$ is in agreement with the data published in several works [1,21]. Priscilla et al. [22] synthesized nanoparticles from $\mathrm{Zn}_{1-x} \mathrm{Mg}_{x} \mathrm{O}$ films ( $x=0,0.2$ and 0.4$)$ deposited by the sol gel method, and the results show that the optical band gap increases from 3.16 to $3.24 \mathrm{eV}$ depending on the $\mathrm{Mg}$ doping concentration. Qiu et al. [23] studied the effect of $\mathrm{Mg}$ doping on the optical properties of $\mathrm{ZnO}$ films for $\mathrm{Mg}$ concentration levels from 0 to 25 at. \%. Consequently, the increase in the optical gap can be attributed to the substitution of $\mathrm{Mg}^{2+}$ ions in the $\mathrm{ZnO}$ matrix. Since the level of $\mathrm{Mg} 3 s$ is higher than that of $\mathrm{Zn} 4 s$, the $\mathrm{Mg} 3 s$ orbital hybridized with $\mathrm{Zn} 4 s$ leads to an increase in the conduction band (CB) edge, thereby increasing the optical gap [23]. Moreover, the increase in the band gap with increasing $\mathrm{Mg}$ content can be explained by the generation of more oxygen and electron vacancies. In addition, the growth of $E_{g}$ (blue shift) for $6 \% \mathrm{~F}: 1 \% \mathrm{Mg}$ co-doping is attributed to the Burstein-Moss. This band gap widening was also observed for other semiconductors such as Mg-doped $\mathrm{ZnO}$ [1], Co-doped $\mathrm{ZnO}$ [2], Nidoped $\mathrm{SnO}_{2}$ [18], Sn-doped $\mathrm{In}_{2} \mathrm{O}_{3}$ and $\mathrm{B} / \mathrm{Mg}$ co-doped $\mathrm{ZnO}$. According to the literature, the same result was observed by Snega et al. [15] by studying films of F/Mg co-doped $\mathrm{ZnO}$ deposited by spray pyrolysis method for concentrations of $\mathrm{Mg}$ varying between 4-16 at. \% and a content of $\mathrm{F}$ equal to 20 at. \%. Therefore, the reason for this blue shift caused by $\mathrm{Mg}$ doping can be explained by the difference in ionic radii of $\mathrm{Zn}^{2+}$ and $\mathrm{Mg}^{2+}$ cations, which causes an increase in defect centers in the $\mathrm{ZnO}$ lattice which can be the reason for this enlargement of $E_{g}$ [15]. So, the introduction of a small amount of $\mathrm{Mg}$ $(\mathrm{Mg}=1 \%)$ improves the optical gap. In addition, still according to Table 3, we also notice a decrease in the band gap when $\mathrm{Mg}$ (2 and $3 \%$ ) is added to $\mathrm{ZnO}: 6 \% \mathrm{~F}$. The same result was observed by $\mathrm{Si}$ et al. [24] by studying $\mathrm{Zn}_{0.97-x} \mathrm{Mg}_{x} \mathrm{Al}_{0.03} \mathrm{O}$ NPs $(x=0,0.01,0.03$ and 0.05$)$ deposited by hydrothermal growth. According to San et al. [25], when the concentration of carriers is greater than the critical Mott transition concentration (CMott), the Urbach tail will narrow the energy gap. 


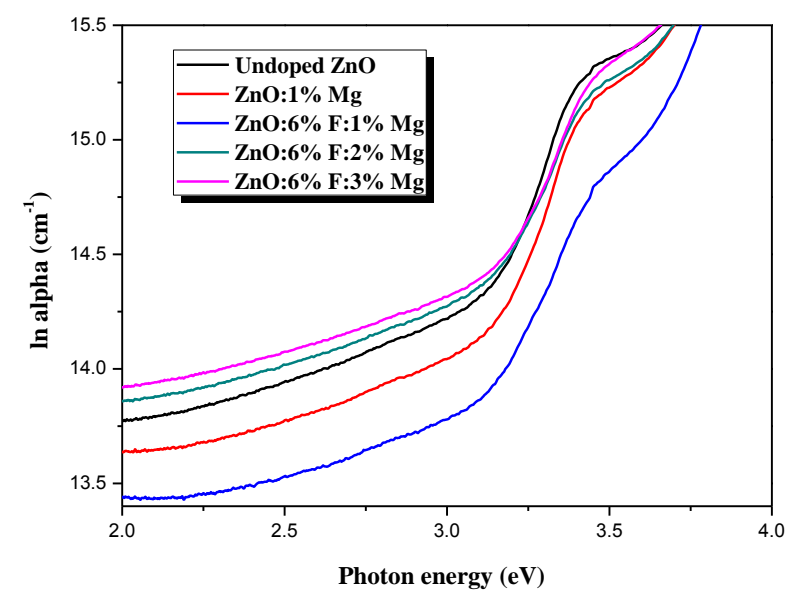

Fig. 7 - Plots of $\ln \alpha$ versus photon energy $h v$ for determining the Urbach energy of $\mathrm{ZnO}$ thin films deposited with different dopant

Irregularities created in the band gap are measured in terms of Urbach energy $\left(E_{U}\right)$ or disorder. Near the edge of the band, the absorption coefficient $(\alpha)$ depends exponentially on the photon energy $(h v)$ according to the following relation [13]:

$$
\alpha=\alpha_{0} \exp \frac{h v}{E_{U}}
$$

where $\alpha_{0}$ is a constant.

The Urbach energy for films of pure $\mathrm{ZnO}, \mathrm{Mg}$-doped and $\mathrm{F} / \mathrm{Mg}$ co-doped is determined by plotting $\ln \alpha$ against the photon energy $h v$, as shown in Fig. 7 . The inverse of the slope of the linear part (Fig. 7) of the curves gives the values of $E_{U}$, which are tabulated in Table 3. It is observed from Table 3 that the Urbach energy for $6 \% \mathrm{~F}: 1 \% \mathrm{Mg}$ co-doped $\mathrm{ZnO}$ film is lower than that of other films. The Urbach energy decreases with the $\mathrm{Mg}$ content equal to $1 \%$ for doping and codoping. However, the value of $E_{U}$ increases for the highest doping of $\mathrm{Mg}$ (2 and $3 \%$ ).

It is well known that strong disorder in the film lattice leads to the formation of small crystallites, the largest crystallite size is $19.149 \mathrm{~nm}$ and the smallest disorder is $330.03 \mathrm{meV}$ for $6 \% \mathrm{~F}: 1 \% \mathrm{Mg}$ co-doped film. This is consistent with a decrease in the value of the defect of the strain calculated from the XRD patterns. This gives a more ordered film. As seen, Table 3 also shows a good correlation between the Urbach energy and the band gap energy. This suggests that the band gap obtained in this work is governed by the disorder.

\section{REFERENCES}

1. R. Sagheer, M. Khalil, V. Abbas, Z.N. Kayani, U. Tariq, F. Ashraf, Optik 200, 163428 (2020).

2. N. Guermat, W. Daranfed, I. Bouchama, N. Bouarissa, J. Mol. Struct. 1225, 129134 (2021).

3. N. Guermat, W. Daranfed, K. Mirouh, Ann. Chimie Sci. Matériaux 44, 347 (2020).

4. M. Krunks, E. Mellikov, Thin Solid Films 270, 33 (1995).

5. Y. Wang, J. Song, H. Zhang, X. Zhang, G. Zheng, J. Xue, B. Han, X. Meng, F. Yang, J. Li, J. Alloy. Compd. 822, 153688 (2020).

6. M. de la L. Olvera, A. Maldonado, R. Asomoza, Sol. Energy
Table 4 - Variation of conductivity of undoped, doped and codoped $\mathrm{ZnO}$ films

\begin{tabular}{|l|c|}
\hline \multicolumn{1}{|c|}{ Sample type } & Conductivity, $(\Omega \cdot \mathrm{cm})^{-1}$ \\
\hline Undoped $\mathrm{ZnO}$ & 0.004 \\
\hline $\mathrm{ZnO}: 1 \% \mathrm{Mg}$ & - \\
\hline $\mathrm{ZnO}: 6 \% \mathrm{~F}: 1 \% \mathrm{Mg}$ & 0.030 \\
\hline $\mathrm{ZnO}: 6 \% \mathrm{~F}: 2 \% \mathrm{Mg}$ & 0.015 \\
\hline $\mathrm{ZnO}: 6 \% \mathrm{~F}: 3 \% \mathrm{Mg}$ & 0.009 \\
\hline
\end{tabular}

The electrical properties of undoped, $1 \% \mathrm{Mg}$ doped and \% F:\% Mg co-doped $\mathrm{ZnO}$ layers are characterized by the four-probe technique. The values of the electrical conductivity of our films are collated in Table 4. Table 4 clearly shows that the electrical conductivity increases and improves with $\mathrm{F} / \mathrm{Mg}$ co-doping, but is not affected by the addition of $1 \% \mathrm{Mg}$ to $\mathrm{ZnO}$ film. $1 \% \mathrm{Mg}$ doped film is more resistive compared to pure $\mathrm{ZnO}$. This result confirms that the presence of fluorine with magnesium improves the conductivity of the deposited films. This behavior is probably due to the degradation of native defects, such as interstitial $\mathrm{Zn}^{2+}$ cations and oxygen vacancies, with the incorporation of $\mathrm{Mg}^{2+}$ cation into the $\mathrm{ZnO}$ matrix.

\section{CONCLUSIONS}

In the present work, we have investigated the performance of pure, Mg-doped and $\mathrm{F} / \mathrm{Mg}$ co-doped $\mathrm{ZnO}$ nanocrystalline thin films on glass substrates by the spray pyrolysis process. The experimental results show that all the films exhibit a typical hexagonal wurtzite structure with a preferred orientation (002) and no impurity phase is observed. The measured contact angles are $>90^{\circ}$ for undoped, doped and $6 \% \mathrm{~F} / 1 \% \mathrm{Mg}$ co-doped $\mathrm{ZnO}$ films, confirming the hydrophilic character, and for other F/Mg co-doped $\mathrm{ZnO}$ films (6 \%:2 \% and $6 \%: 3 \%$ ) a hydrophilic character is manifested at values of the contact angle $<90^{\circ}$. The UV-visible absorption spectra of all the materials have a high transmittance value of $86.47 \%$ for $6 \% \mathrm{~F}: 1 \% \mathrm{Mg}$ codoping. The calculated results show that the band gap of the $\mathrm{ZnO}$ material increases after co-doping with a small amount of $\mathrm{Mg}\left(1 \% \mathrm{Mg}, E_{\text {gmax }}=3.53 \mathrm{eV}\right)$. Electrical analysis demonstrates that $6 \% \mathrm{~F} / 1 \% \mathrm{Mg}$ co-doping improves conductivity $\left(\sigma=0.030(\Omega \cdot \mathrm{cm})^{-1}\right)$. We deduce that $6 \% \mathrm{~F} / 1 \% \mathrm{Mg}$ co-doping can be considered optimal for the preparation by spray pyrolysis of $\mathrm{ZnO}$ films with better structural, optical, hydrophobic and electrical characteristics required as a buffer layer in solar cells.

Mater. Sol. C. 73, 425 (2002)

7. G. Liu, T. Guo, G. Xu, J. Ma, Y. Yang, S. Tan, Opt. Mater. 95, 109213 (2019).

8. K. Verma, B. Chaudhary, V. Kumar, V. Sharma, M. Kumar, Vacuum 146, 524 (2017).

9. T.M. Hammad, J.K. Salem, J. Nanopart. Res. 13, 2205 (2011).

10. M.R. Islam, M. Rahman, S.F.U. Farhad, J. Podder, Surf. Interface 16, 120 (2019).

11. Ch.L. Lin, F.H. Wang, H.S. Jhuang, Ch.F. Yang, J. Mater. Res. Technol. 9, 6331 (2020).

12. H. Chen, J. Ding, S. Ma, Physica E 42, 1487 (2010). 
13. W. Daranfed, N. Guermat, I. Bouchama, K. Mirouh, S. Dilmi, M.A. Saeed, J. Nano-Electron. Phys. 11 No 6, 06001 (2019).

14. Y.Ch. Cho, S.Y. Cha, J.M. Shin, J.H. Park, S.E. Park, Ch.R. Cho, S. Park, H.K. Pak, S.Y. Jeong, A.R. Lim, Solid State Commun. 149, 609 (2009).

15. S. Snega, K. Ravichandran, N. Jabena Begum, K. Thirumurugan, J. Mater. Sci. Mater. Electron. 24, 135 (2013).

16. P.P. Rath, S.S. Behera, B. Priyadarshini, S.R. Panda, D. Mandal, T. Sahoo, S. Mishra, Tapas R. Sahoo, P.K. Parhi, Appl. Surf. Sci. 491, 256 (2019).

17. W. Daranfed, N. Guermat, K. Mirouh, Ann. Chimie Sci. Matériaux 44, 121 (2020).

18. M. Khalfallah, N. Guermat, W. Daranfed, N. Bouarissa, H. Bakhti, Phys. Scripta 95, 095805 (2020).
19. G. Kasi, J. Seo, Mater. Sci. Eng. C. 98, 717 (2019).

20. Y. Li, Y. Li, A. Xie, Coatings 11, 882 (2021).

21. S. Liu, L. Zhu, W. Cao, P. Li, Z. Zhan, Z. Chen, X. Yuan, J. Wang, J. Alloy. Compd. 858, 157654 (2021).

22. S. Janet Priscilla, R. Daniel, Y. Dhakshayani, S. Charis Caroline, K. Sivaji, Mater. Today: Proc. 36, 793 (2021)

23. X. Qiu, L. Li, J. Zheng, J. Liu, X. Sun, G. Li, J. Phys. Chem. C 112, 12242 (2008)

24. X. Si, Y. Liu, W. Lei, J. Xu, W. Du, J. Lin, T. Zhou, L. Zheng, Mater. Des. 93, 128 (2016).

25. H.S. San, B. Li, B.X. Feng, Y.Y. He, C. Chen, Acta Physica Sinica 54, 842 (2005).

\title{
Порівняльне дослідження оптоелектронних характеристик нелегованих, легованих Мg та спільно легованих F/Mg нанокристалічних тонких плівок ZnO для застосування в сонячних елементах
}

\author{
Warda Darenfad ${ }^{1}$, Noubeil Guermat ${ }^{1,2}$, Kamel Mirouh ${ }^{1}$ \\ 1 Thin Films and Interfaces Laboratory (LCMI), University of Brothers Mentouri of Constantine 1, \\ 25000 Constantine, Algeria \\ ${ }^{2}$ Department of Electronics, Faculty of Technology, University Mohamed Boudiaf of M'sila, 28000 M'sila, Algeria
}

\begin{abstract}
У роботі повідомляеться про розробку та характеристики нанокристалічних тонких плівок оксиду цинку $(\mathrm{ZnO})$, нанесених на скляні підкладки методом спрей-піролізу. Досліджено вплив легування $1 \% \mathrm{Mg}$ та спільного легування $6 \% \mathrm{~F} / x \% \mathrm{Mg}(x=1,2$ and 3) на структурні, морфологічні, оптичні та електричні властивості отриманих плівок. Структурна характеризація показуе, що всі нанесені шари е полікристалічними з гексагональною структурою типу вюрцит, оскільки фіксуеться більш інтенсивний пік відносно піку (002), який розташований поблизу $34,13^{\circ}$, без жодної іншої фази. Виміряні контактні кути становлять більше $90^{\circ}$ для чистих, легованих та спільно легованих $6 \% \mathrm{~F} / 1 \% \mathrm{Mg}$ плівок, що підтверджуе гідрофобний характер, тоді як інші спільно леговані плівки (6\% F:2\% $\mathrm{Mg}$ та $6 \% \mathrm{~F}: 3 \% \mathrm{Mg}$ ) мають гідрофільний характер при значеннях контактного кута $<90^{\circ}$. Більш високе значення коефіціента пропускання 86,47 \%, широка заборонена зона $3,53 \mathrm{eB}$ і менша ступінь розупорядкування (330,03 меВ) спостерігаються для плівки, спільно легованої 6 \% F:1 \% Mg. Спільне легування $1 \% \mathrm{Mg}$ значно покрашуе електропровідність $\left(\sigma=0,030(\Omega . c \mathrm{M})^{-1}\right)$. Результати свідчать про те, що спільно леговану плівку $\mathrm{ZnO}(6 \% \mathrm{~F}, 1 \% \mathrm{Mg})$ можна використовувати як віконну плівку в тонкоплів-
\end{abstract} кових сонячних елементах.

Ключові слова: Тонкі плівки; ZnO, спільно легований F/Mg, Спрей-піроліз, Контактний кут, Гідрофобний, Гідрофільний. 